\title{
Student's Self-Confidence and Their Learning Achievement on Elementary Schools
}

\author{
Gamar Abdullah \\ Department of Elementary Teacher Education \\ Universitas Negeri Gorontalo, Indonesia \\ gamar@ung.ac.id
}

\author{
Isnanto \\ Department of Elementary Teacher Education \\ Universitas Negeri Gorontalo, Indonesia \\ isnanto@ung.ac.id
}

\author{
Ni Putu Yuni Vidiyanti \\ Department of Elementary Teacher Education \\ Universitas Negeri Gorontalo, Indonesia \\ putuyunividiyanti@gmail.com
}

\begin{abstract}
Self-confidence is a very important aspect for someone to be able to develop their potential. If students have good self-confidence, then students can develop their potential well. The purpose of this study is to determine the correlation between student's self-confidence and the learning achievement of Elementary Schools in Kota Tengah Sub-district. This is generated from the problem of the research. To find out the correlation, a quantitative research approach with ex post facto method was employed. This study involved students from all public elementary schools in the Kota Tengah Sub-district as the population of the research with samples of 80 respondents. Data collection techniques used documentation, questionnaires, and observations. Meanwhile, data analysis techniques applied the Spearman rank test and T-test. Based on the hypothesis test that has been done, it was found that there is a relationship of self-confidence with the learning achievement. Moreover, significant test of correlation also obtainsthe outcome in the medium category. Therefore, it can be stated that there is a correlation between student's self-confidence and the learning achievement on Elementary Schools.
\end{abstract}

Keywords: achievement, learning, self-confidence

\section{INTRODUCTION}

Education is the most important part in the aspect of life as a provision in order to form intelligent and quality human beings. The most basic level of formal education in Indonesia is an elementary school that is taken for six years, consisting of the first to sixth grade.

The process of formal education is always related to the learning process in the classroom. In class, teachers and students are involved in a series of teaching and learning processes. Learning is a mental or psychological activity that takes place in active interaction with the environment and produces changes in knowledge and understanding, skills and values and attitudes, both in the daily life environment and academics [1]. The purpose of the learning process is to achieve an optimal learning outcome and satisfying achievement. Learning achievement is the result of assessment of the learning process and student learning outcomes in accordance with the instructional objectives expected of students.

Each student has different achievements depending on the abilities they have, usually classified into three, namely high, medium and low achievement. However, not all students are able to achieve good achievements, even to achieve maximum scores students often take unexpected actions, such as cheating. This is influenced by several factors, one of which is the level of confidence students have.

Self-confidence is a very important aspect for someone to be able to develop their potential. If students have good self-confidence, then students can develop their potential well. But on the contrary, if students have low self-confidence, then these students tend to close themselves, easily frustrated when faced with difficulties, awkward in facing other people, and difficult to accept the reality of themselves. Having high self-confidence in students can help them achieve good learning achievement. That way there will be a process of change in students not only on learning achievement but also on the behavior and attitudes of students, namely courage, activity, and self-actualization of students during the teaching and learning process.

Differences in self-confidence and student achievement at the elementary school level can be seen from observations made at one of the elementary schools in Kota Tengah sub-district in September 2018, where there are students who are very prominent or active in participating in the teaching and learning process in the classroom and there are students who have a tendency to close themselves or do not want to express their opinions in public, especially in the teaching and learning process, because of their inferiority or self-confidence. A student who is not confident cannot express his feelings, thoughts and aspirations to others, so they will always be afraid and hesitant to step and act. This causes the goals to be achieved will be difficult to materialize, so the potential that actually exists in him cannot be utilized optimally. Likewise the learning achievements achieved by students show differences between students with one another.

Based on the background above, the research was conducted with the aim of knowing the relationship of self-confidence with the learning achievement of students of Elementary Schools in Kota Tengah Sub-district, Gorontalo City. 


\section{LITERATURE REVIEW}

\section{A. Learning Achievement}

Achievement is a change in behavior that is expected in students after the learning process is carried out [2]. Achievement is a special and real skill that someone achieves maximally as a result of learning [3]. Achievement is everything that has been created, results of work, results that are pleasing to the heart that are obtained by the tenacity of work [4]. Achievement is the result obtained by someone, be it achievement at school, at work or other. Achievement is the result of an activity that has been done, created both individually and in groups. Based on the opinions of experts, it can be concluded that achievement is everything that has been achieved by someone for the work or effort that has been done [5].

According to behavioristic theory, learning is a change in behavior as a result of the interaction between stimulus and response. In other words, learning is a form of change experienced by students in terms of their ability to behave in new ways as a result of interactions between stimulus and response. A person is considered to have learned something if he can show changes in his behavior [5]. Learning is a process of behavior change that is pleasing to the mastery and addition of knowledge, skills, attitudes, values, motivations, habits, interest in appreciation, and so forth as a result of interactions with the environment concerning individual personalities [6] Learning is a process of change in the human personality, and these changes are manifested in the form of increasing quality and quantity of behavior such as increasing skills, knowledge, attitudes, habits, understanding, skills, thinking power, and other abilities [7].

Learning achievement is the result of learning activities achieved by students in the form of knowledge, attitudes, skills and skills that are usually formulated in the form of numbers or letters and rewards students who are considered successful [2] Learning achievement is the result of a good learning process, characterized by the ability to perceive material about related subjects and the overall results

According to Bloom, academic achievement or learning achievement is the learning process experienced by students and produces changes in the fields of knowledge, understanding, application, power of analysis, synthesis, and evaluation. Student learning achievement is the learning outcomes achieved by students when following and doing assignments and learning activities in school [9]. Learning achievement is mainly assessed by cognitive aspects because it is concerned with students abilities in knowledge or memory, understanding, application, analysis, synthesis and evaluation. Student learning achievement is proven and shown through the value or number of values from the results of evaluations conducted by the teacher on the students' assignments and the repetitions or tests that they take [10].

\section{B. Self-Confidence}

Learning achievement is a thing that cannot be separated from learning activities, because learning activities are processes, while achievement is the result of the learning process. Learning achievement is a measure of success obtained by students during the learning process. Success is determined by several interrelated factors. According to factors that influence student learning achievement are divided into two, namely Internal factors and External factors [10]. Internal factors are factors that come from within a person that can affect their learning achievement. Internal factors consist of physiological and psychological factors. While external factors include family factors, school environment and society.

Self-confidence is one of the factors that influence student achievement. Self-confidence means believing in your ability, strength and self-assessment. The assessment of self in question is a positive assessment. The assessment will later lead to a motivation in the individual to be more appreciative of himself. Self-confidence is a belief in all aspects that are owned and that belief makes him feel able to be able to achieve various goals in his life [11].

Self-confidence is the most valuable attribute in a person in social life [12]. Due to self-confidence, a person is able to actualize all of his potential. The element of self-confidence is the ability to handle strong feelings in certain ways in order to solve problems quickly. Taylor also revealed that without self-confidence, someone would be like "wallpaper visible, but invisible". Talents are left hidden, opportunities are ignored, people are skipped because they do not have the confidence to advance. [13].

Self-confidence is a vital key for someone to achieve success in personal and work life. Self-confidence enables one to overcome new challenges, believe in oneself in difficult situations, overcoming obstacles that limit, resolve things that have never been done, and issue talents and abilities fully. Self-confidence gives someone the courage not to worry about failure. Characteristics of people who are confident are more focused on what can be done and the positive results that will be achieved, not on what they cannot do and what might be wrong. Without self-confidence, life's challenges will be difficult to overcome [14].

Based on the opinions of the experts above, it can be concluded that self-confidence is a belief held by a person to express all abilities possessed without fear or doubt, so that the person can face all challenges in his life.

\section{Characteristics of People Who Have Self- Confidence}

People who have confidence have the following characteristics; 1)Believing in one's own abilities is a belief in oneself against all phenomena that occur that are related to the individual's ability to evaluate and overcome the phenomena that occur; 2)Able to do it own, namely being able to act independently or without the involvement of other people both in acting and in making decisions about themselves; 3)Positive thinking about yourself is the existence of a good judgment from within ourselves, both from the views and actions taken that give rise to a positive feeling towards themselves and their future; 4)Courageous is the existence of an attitude to be able to express something in themselves that wants to be 
revealed to others without any coercion or feeling that can hinder such disclosure [15].

\section{METHOD}

The research was conducted in January-April 2019. This research was conducted at the Elementary School in Kota Tengah Sub-district, Gorontalo City, which consisted of 12 schools.

This study uses a quantitative approach, to determine the existence of a relationship of one independent variable with one dependent variable. This study included ex post facto research methods which meant research after the event. The ex post facto research method was used to determine the relationship between self-confidence and student achievement in the Elementary Schools in Kota Tengah Sub-District, Gorontalo City. The variables in this study input bebaI variables and dependent variables. The independent variable in this study is self-confidence while the dependent variable is learning achievement.

The data in this study were collected using the method of documentation and questionnaires. Documentation is used to collect data on student achievement. Data on student learning achievement is obtained from the documentation of homeroom in the odd semester of the school year 2018-2019. Students who are sampled are students who have high rankings in public elementary schools in Kota Tengah Sub-district, Gorontalo City.

While the questionnaire is used to obtain the confidence data students have. Confidence data is obtained through the results of scoring questionnaires distributed to respondents namely public elementary school students in Kota Tengah Subdistrict, Gorontalo City in the 2018-2019 school year. Indicators of selfconfidence include (1) Believing in one's own abilities, (2) being independent, (3) thinking positively about oneself and (4) being brave.

The population in this study were fifth grade students of Elementary Schools in Kota Tengah Subdistrict, Gorontalo City with a total of 400 students in the 2018-2019 academic year spread in 12 schools. The sample was selected using a purposive sampling technique. The formula used to determine the size of the sample size that has been studied in this study is by using the Slovin formula. Based on calculations, the sample size that must be taken in this study is 80 students.

The data analysis technique used in this study is a nonparametric statistical form. Because the data obtained in this study are in the form of interval and ordinal data, the interval data is converted into ordinal data using normative reference assessment techniques. Thus, the data is of the same type and can be processed using nonparametric statistics. Hypothesis testing is done using the Spearman rank formula with the help of SPSS and Ttest using SPSS 23.

\section{A. Description of Self-Confidence Data \\ IV. RESULTS AND DISCUSSION}

Self-confidence is a belief that is owned by someone to express all their abilities without fear or doubt, so that the person can face all the challenges that exist in his life.

The initial stage of this research is to arrange questionnaires according to the indicators of selfconfidence. The indicators of self-confidence in this study consisted of four indicators, where the first indicator was self-confidence consisting of 10 questionnaire items, the second indicator which consisted of 8 questionnaire items, the third indicator was positive thinking about yourself consisting of 8 questionnaire items, and the fourth indicator, which is bold, consists of 10 questionnaire items. The researcher conducted research in the fifth grade of the Elementary School in Kota Tengah Subdistrict, Gorontalo City. The next stage is the researchers circulate questionnaires to class $\mathrm{V}$ students as respondents in accordance with the sample size that has been determined. Before students fill out the questionnaire, the researcher explains the procedure in filling out the questionnaire to students so that students are able to fill in the self confidence questionnaire according to their actual situation.

Based on the results of data processing with the help of SPSS 23 the frequency of descriptive statistics was obtained as shown in Figure 1.

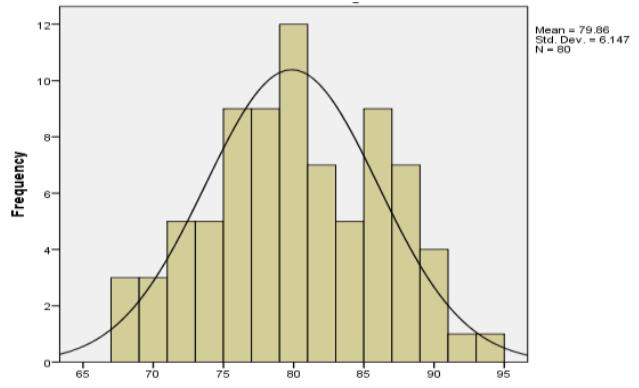

Figure 1. Student Confidence Histogram

Based on Figure 1, it can be seen that the histogram of the results of students' self-confidence with the mean is 79.86, the standard deviation is 6.147 and the sample number is 80 . From the histogram above, it can be seen that the student's highest frequency is 80 .

\section{B. Hypothesis testing}

To see the correlation between students' selfconfidence and their learning achievement can be seen after hypothesis testing. Hypothesis testing in this study was carried out using the Spearman Rank formula with the help of SPSS 23.

\begin{tabular}{|c|c|c|c|c|}
\hline \multicolumn{5}{|c|}{ Correlations } \\
\hline & & & $\begin{array}{l}\text { Kepercayaan } \\
\text { Diri }\end{array}$ & $\begin{array}{c}\text { Prestasi } \\
\text { Belajar }\end{array}$ \\
\hline \multirow[t]{6}{*}{ Spearman's rho } & \multirow[t]{3}{*}{ Kepercayaan Diri } & Correlation Coefficient & 1.000 & $.573^{\text {"1" }}$ \\
\hline & & Sig. (2-tailed) & & .000 \\
\hline & & $\mathrm{N}$ & 80 & 80 \\
\hline & \multirow[t]{3}{*}{ Prestasi Belajar } & Correlation Coefficient & $.573^{\mathrm{km}}$ & 1.000 \\
\hline & & Sig. (2-tailed) & .000 & \\
\hline & & $\mathrm{N}$ & 80 & 80 \\
\hline
\end{tabular}

Figure 2 Correlation Results of Confidence and Student Learning Achievement 
Self-confidence and student achievement show a correlation or relationship between self-confidence and student achievement. The value obtained is 0.573 with a significant 0.000 in the sample amounting to 80 . The following is a table of details of the results of data processing. Figure 2 shows a significant correlation between student confidence and learning achievement. This is evidenced by the significant results of $0,00050,05$ and the level of the relationship is classified in the same category as the value of 0,573 is between $0,40-0,599$.

After getting the results of the correlation test, it is continued by doing the t-test to find out the significant level of correlation. The calculation results show that thitung $=8.830$ abel $\mathrm{t}$ table $=1.990$, so based on the testing criteria $\mathrm{H} 0$ is rejected and $\mathrm{H} 1$ is accepted. That is, there is a relationship of self-confidence with the learning achievement of fifth grade students in the Elementary Schools in Kota Tengah Sub-district, Gorontalo City.

\section{Discussion}

In the teaching and learning process students must have confidence. Self-confidence is a belief that is owned by someone to express all their abilities without fear or doubt, so that the person can face all the challenges that exist in his life. The characteristics of students who have self-confidence are to believe in their own abilities, to be independent, to think positively about themselves, and to be brave.

Self-confidence is one of the factors that influence student achievement. Learning achievement is the result obtained by students in the learning process that contains cognitive, affective, and psychomotor aspects through educator assessment. Self-confidence will make students able to act with all beliefs. A good level of selfconfidence will make it easier for students to express their opinions and make decisions to do something positive especially in learning, so self-confidence is very important in supporting students to achieve learning achievement.

Students who have self-confidence will believe in their own abilities, namely a belief in themselves against all phenomena that occur that are related to their ability to evaluate and overcome the problems they face. These students also have a big tendency to be independent. Shiva is able to act independently or without the involvement of other people both in acting and in making decisions about themselves. In addition, these students will tend to think positively about themselves, namely the existence of a good judgment from within themselves, both from the views and actions taken that lead to a positive feeling towards themselves and their future. These students will always be brave and able to express something in themselves that they want to express to others without any coercion or feeling that can hinder such disclosure.

\section{CONCLUSION}

Based on the results of research that has been stated that there is a relationship of self-confidence with the learning achievement of fifth grade students of
Elementary Schools in Kota Tengah Sub-district, Gorontalo City.

Based on the research that has been done on the relationship of self-confidence with the learning achievement of fifth grade students of the Elementary School in Kota Tengah Subdistrict, Gorontalo City, the researcher expects that the school especially the teacher always pay attention to factors related to student achievement including the confidence possessed by students. Either by applying a model or method that can increase student self-confidence.

\section{REFERENCES}

[1] A Suprihatiningrum, Jamil. "Strategi Pembelajaran". Jogjakarta: Ar-Ruzz Media, 2016.

[2] Firdianti, Arianda. "Implementasi Manajemen Berbasis sekolah dalam meningkatkan Prestasi Belajar Siswa". Yogyakarta: CV GRE Publishing. 2018.

[3] Malinda. "Penerapan Model Pembelajaran PBL untuk Meningkatan Prestasi belajar Siswa Pada Mata Pelajaran Ekonomi Materi Pokok Pencatatan Transaksi Perusahaan Dagang dan Jurnal Khusus Kelas XII SMA". http://books.google.co.id. 2018.

[4] Djumuli, Fatmah. "Hubungan Tingkat Pendidikan Orang Tua Terhadap Prestasi Belajar Siswa Se-Kecamatan Bulango Utara”. Gorontalo: Universitas Negeri gorontalo. 2017.

[5] Budiningsih, Asri. "Belajar dan Pembelajaran". Jakarta: PT Rineka Cipta. 2012

[6] Jumalia. "Pengaruh Kepercayaan Diri Dan Kemampuan Komunikasi Matematika Terhadap Hasil Belajar Matematika Siswa Kelas VIIi SMP Negeri 5 Majene”. http://eprints.unm.ac.id/6406/. 2018

[7] Hakim, Thursan. "Belajar Secara Efektif". Jakarta: Pustaka Pembangunan Swadaya Nusantara. 2010

[8] Komara, Indra Bangkit. "Hubungan antara Kepercayaan Diri dengan Prestasi Belajar dan Perencanaan Karir Siswa": Jurnal Psikopedagogia Universitas Ahmad Dahlan, Vol. 5, No. 1 ISSN: 2301-6167. 2016

[9] Hawadi, Akbar Reni. "Akselerasi A-Z, Program Percepatan Belajar dan Anak Berbakat Intelektual". Jakarta: Grasindo, 2004

[10] Marbun, Stefanus M. "Psikologi Pendidikan". Ponorogo: Uwais Inspirasi Indonesia, 2018

[11] Aristiani. “ Meningkatkan Percaya Diri Siswa Melalui Layanan Informasi Berbantuan Audiovisual": Jurnal Konseling Gusjigang Vol. 2 No. 2 Issn 2460-1187, Issn 2503-281. http://jurnal.umk.ac.id/ index.php/gusjigang/article/view/717/716. 2016

[12] Sardin dan Nurmita. "Pembelajaran Matematika Humanis Dengan Metaphorical Thinking Untuk Meningkatkan Kepercayaan Diri Siswa": Jurnal Penelitian dan Artikel Pendidikan, Vol. 9 No. 1, pISSN: 2085-1472, eISSN: 2579-4965. http://journal.ummgl.ac.id/ index.php/edukasi/article/view/853. 2017

[13] Taylor, Ros. 2011. "Kiat-Kiat PEDE". Jakarta: PT Gramedia Pustaka Utama. 2011

[14] Perry, Martin. "Confidence Boosters". London: Octopus Puplising Group. 2005

[15] Safitri, Dini Anugrah. "Hubungan Rasa Percaya Diri dengan Hasil Belajar Matematika Siswa Kelas V SDN Kramat Jati 19 Pagi”. http://repository.uinjkt.ac.id. 2015 